\title{
2-DE-based proteomic analysis of protein changes associated with etiolated mesocotyl growth in Zea mays
}

\author{
Liangjie Niư ${ }^{\dagger}$ Zhaokun $\mathrm{Wu}^{\dagger}$, Hui Liu, Xiaolin Wu and Wei Wang ${ }^{*}$ (D)
}

\begin{abstract}
Background: The mesocotyl connects the coleoptilar node and the basal part of the seminal root of maize (Zea mays) seedling. The mesocotyl pushes the shoot of the seedling out of the soil during seed germination; thus, its growth is highly related to deep-sowing tolerance. Although many studies on the maize mesocotyl have been carried out at physiological and molecular levels, the proteomic changes associated with cellular and physiological activities during mesocotyl growth are still unknown.
\end{abstract}

Results: In the present study, the maize hybrid Zhengdan 958 was used to study mesocotyl growth and accompanying protein changes. The dark-grown etiolated mesocotyls exhibited a slow-fast-slow feature, with significant changes in the levels of indole-3-acetic acid (IAA) and cellulose and the activity of peroxidase (POD). In particular, POD activity increased with mesocotyl growth, showing higher activity at the mature (lower) end of the mesocotyl. For the proteomic analysis, soluble proteins were extracted from etiolated mesocotyls dark-grown for $48 \mathrm{~h}, 84 \mathrm{~h}$, and $132 \mathrm{~h}$, corresponding to the initial, rapid, and slow growth periods, respectively, and subjected to separation by two-dimensional gel electrophoresis (2-DE). As a result, 88 differentially abundant proteins (DAPs) were identified using MALDI-TOF-TOF analysis. At $48 \mathrm{~h}$, most DAPs were stress proteins, heat shock proteins and storage proteins; at $84 \mathrm{~h}$, oxidation/reduction proteins, carbohydrate biogenesis-related proteins and cytoskeletonrelated proteins were highly accumulated; at $132 \mathrm{~h}$, the most striking DAPs were those involved in the synthesis and modification of the cell wall and the biogenesis of carbohydrates. Gene ontology (GO) analysis showed that changes in the abundance and proportion of DAPs were consistent with cellular and physiological activities and biological processes during mesocotyl growth. The accumulation of nine DAPs of interest was verified by immunoblotting and RT-qPCR.

Conclusions: The present study revealed that the protein patterns in 2-D gels differed greatly with mesocotyl growth. At different growth periods, a specific set of DAPs participate in various biological processes and underlie the cellular and physiological activities of the mesocotyl. These results contributed to the understanding of mesocotyl growth and the cultivation of maize lines with deep-sowing tolerance.

Keywords: Mesocotyl growth, 2-DE, Proteomic analysis, Differential abundance protein (DAP), Zea mays

\footnotetext{
* Correspondence: wangwei@henau.edu.cn

${ }^{\dagger}$ Liangjie Niu and Zhaokun Wu contributed equally to this work.

State Key Laboratory of Wheat and Maize Crop Science, College of Life

Sciences, Henan Agricultural University, Zhengzhou 450002, China
}

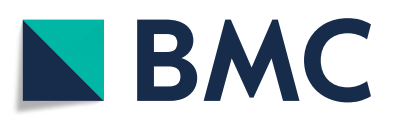

(C) The Author(s). 2019 Open Access This article is distributed under the terms of the Creative Commons Attribution 4.0 International License (http://creativecommons.org/licenses/by/4.0/), which permits unrestricted use, distribution, and reproduction in any medium, provided you give appropriate credit to the original author(s) and the source, provide a link to the Creative Commons license, and indicate if changes were made. The Creative Commons Public Domain Dedication waiver (http://creativecommons.org/publicdomain/zero/1.0/) applies to the data made available in this article, unless otherwise stated. 


\section{Background}

The maize mesocotyl is an organ that connects the coleoptilar node and the basal part of the seminal root in young seedlings [1]. The mesocotyl consists of one centrally localized vascular stele and a hollow cylinder of cortical cells bounded by an epidermal layer [2]. The mesocotyl can be longitudinally divided into three parts: the apical meristematic part, the middle elongation part and the lower mature part [3]. This structure plays two important roles during early seedling establishment. First, the elongating mesocotyl elevates the coleoptile and enclosed plumule towards the soil surface [4]; and second, the cortical aerenchyma inside the mesocotyl supports the initiation and growth of adventitious roots [5]. Therefore, the elongated mesocotyl is highly related to maize deep-sowing tolerance.

Maize mesocotyl growth is attributable to cell division and turgor-driven wall expansion, which is regulated by internal and environmental factors, such as phytohormones [6-9], light [10-13] and gravity [14-16]. In particular, its growth is inhibited by red light via phytochrome action [17] and along with the decrease in the level of auxins in epidermal cells [12, 18, 19]. Moreover, maize mesocotyl growth is regulated by various phytohormones [10, 12, 20], auxin-binding proteins $[21,22]$ and vacuolar $\mathrm{H}^{+}$-ATPase [11]. In particular, polyamine oxidases in mesocotyl epidermal cells are actively involved in cell wall stiffening processes during the light-stimulated inhibition of mesocotyl growth [23]. Additionally, several quantitative trait loci or genes related to deep-sowing tolerance have been identified $[24,25]$. Although many studies on maize mesocotyl growth have been carried out at physiological and molecular levels, there remains a lack of proteomic analysis of protein changes associated with cellular and physiological activities in the mesocotyl.

In the present study, the dark-grown (etiolated) mesocotyls of maize were used for two-dimensional electrophoresis (2-DE)-based proteomic analysis to identify differentially abundant proteins (DAPs) during mesocotyl growth. The DAPs were functionally classified with gene ontology (GO) analysis. Our results revealed that unique sets of DAPs played crucial roles during different growth periods of the mesocotyl.

\section{Results}

\section{Maize mesocotyl growth changes with sowing depth}

To determine the contribution of mesocotyl elongation to seed germination, we compared the length changes of the mesocotyl and the coleoptile at 5,10 and $15 \mathrm{~cm}$ sowing depths (Fig. 1a,b). The assay was performed at 14 days after sowing when the lengths of mesocotyl and coleoptile were fixed. The length of the mesocotyl and the coleoptile increased with sowing depth, especially the mesocotyl. In all cases, the mesocotyl made a greater contributed to seed germination in soil than did the coleoptile (Fig. 1c) because the mesocotyl consistently grew in the soil (dark), whereas the coleoptile growth was inhibited by light upon emergence. Seedling emergence was significantly delayed at a $15-\mathrm{cm}$ depth, resulting in poorly uniform seedlings; however, seedling emergence at 14 days showed no significant difference among different sowing depths (Fig. 1d).

\section{Maize mesocotyl growth in vivo and in vitro}

The etiolated mesocotyl showed a slow-fast-slow growth pattern during the initial growth period (36-48 h), the rapid growth period $(48-132 \mathrm{~h})$ and the slow growth period $(132-156 \mathrm{~h})$. The final length was $7.40 \pm 0.15 \mathrm{~cm}$, with a maximum growth rate at $84 \mathrm{~h}(1.30 \pm 0.16 \mathrm{~mm} / \mathrm{h})$ (Fig. 2a). The fresh and dry weights and cellulose content of the mesocotyl significantly increased with growth, but the protein content and the relative water content (RWC) changed little from $84 \mathrm{~h}$ onward (Table 1a).

The IAA content in elongating mesocotyls was analyzed per fresh weight. As expected, IAA increased rapidly during $48-96 \mathrm{~h}$, corresponding to the rapid growth period (Fig. 2b). In 84-h-old mesocotyls, the IAA content varied in different parts, with the highest in the $5-20 \mathrm{~mm}$ region of the elongation zone (Fig. 2c). Light microscopy showed that the size of mesocotyl cells increased with time (Fig. 2d) and with cell maturation (from upper to bottom) (Fig. 2e). Thus, the size of mesocotyl cells was positively correlated with the IAA content. Additionally, the upper half of the mesocotyl exhibited quick division and growth both in vivo and in vitro (Fig. 2f).

Mesocotyl segments displayed rapid growth in the presence of IAA, and there was no significant difference between $10 \mu \mathrm{M}$ and $100 \mu \mathrm{M}$ (Fig. 2g). Therefore, $10 \mu \mathrm{M}$ IAA was used in further analysis. Similar to in vivo growth, mesocotyl in vitro also showed a slow-fast-slow growth pattern. After incubation for $24 \mathrm{~h}$, the length of mesocotyl segments increased from $10 \mathrm{~mm}$ to $16.66 \pm$ $0.79 \mathrm{~mm}$, with the maximum growth rate at $12 \mathrm{~h}(0.24 \pm$ $0.01 \mathrm{~mm} / \mathrm{h}$ ) (Fig. 2h). The fresh weight, RWC and cellulose content of the mesocotyl segments significantly increased with in vivo growth, but the protein content decreased (Table 1b).

\section{Protein changes during maize mesocotyl growth}

The protein accumulation differences of the mesocotyls at $48 \mathrm{~h}, 84 \mathrm{~h}$ and $132 \mathrm{~h}$ were analyzed by $2-\mathrm{DE}$ with $\mathrm{pH}$ 4-7 IPG strips. In general, the distribution patterns of the protein spots on 2-DE gels were similar among the three growth periods (Fig. 3, Additional file 4: Figure S1), but each period had a specific set of differential abundance proteins (DAPs) (Fig. 4a).

After ANOVA and Student's t test $(p<0.05 ; n=3), 89$ DAPs with at least 2-fold differences in relative abundance 

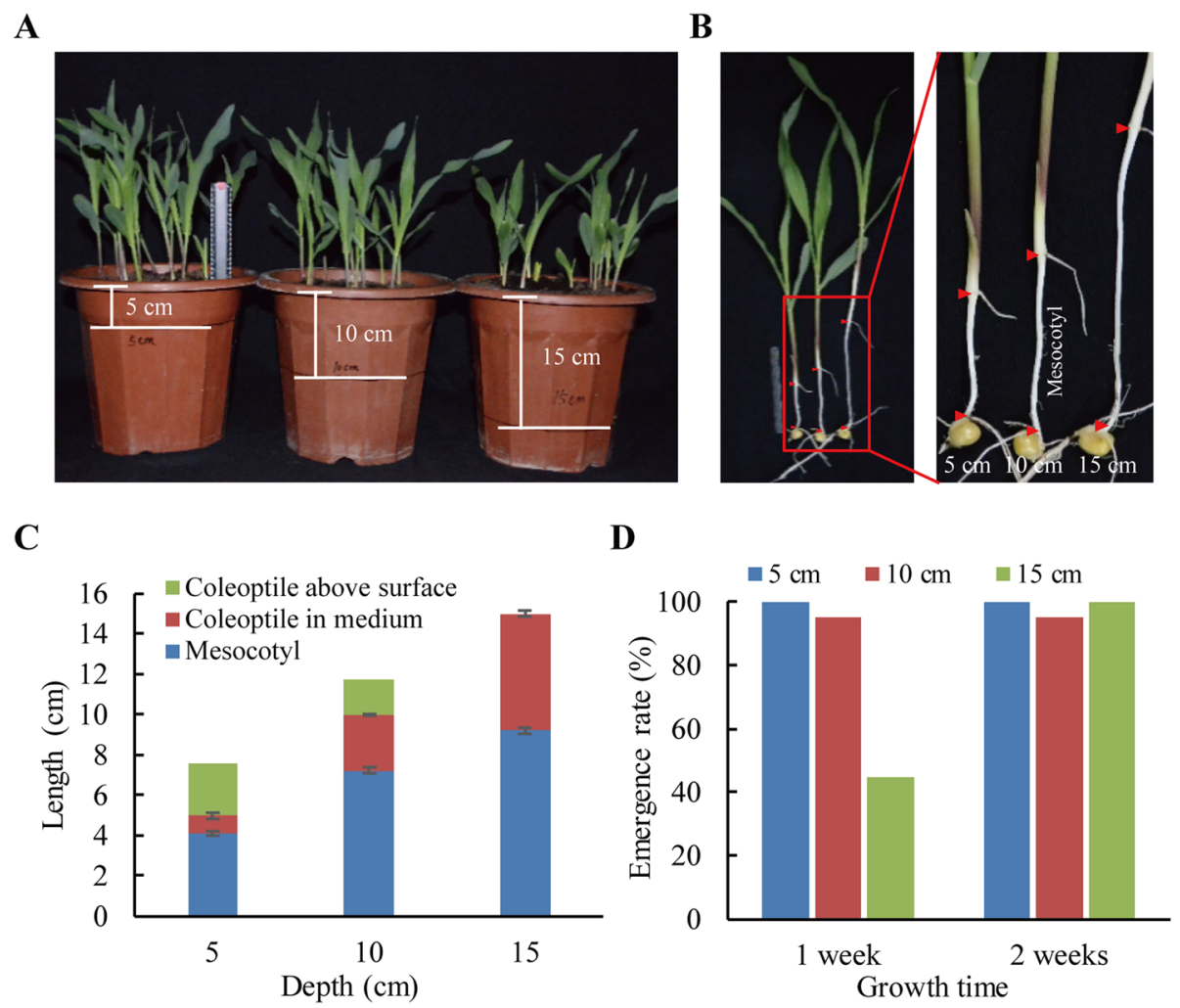

Fig. 1 Mesocotyl length at different sowing depths. Maize seedlings were grown under a photoperiod with $16 \mathrm{~h}$ light $\left(80-100 \mu \mathrm{E} \mathrm{m} \mathrm{m}^{-2} \mathrm{~s}^{-1}, 28^{\circ} \mathrm{C}\right)$. After two weeks, the lengths of mesocotyl and coleoptile and the germination rate were measured. a Seedlings at different sowing depths. $\mathbf{b}$ Three representative seedlings showing changes in mesocotyl length with sowing depth. $\mathbf{c}$ The lengths of mesocotyl and coleoptile at different sowing depths. $\mathbf{d}$ Germination rate at different sowing depths. The data represented the results from three independent experiments (mean \pm $\mathrm{SE})$, and at least 15 seedlings were measured in each assay

(Additional file 1: Table S1) were selected for protein identification with MALDI-TOF/TOF analysis. Except for spot 64,88 other DAPs were successfully identified (Additional file 2: Table S2). These DAPs exhibited good coverage regarding molecular weight (MW) and isoelectric point ( $I$ ) (Fig. 4b,c). Most DAPs had a high sequence coverage (20\%) with at least three matched sequences (Fig. 4d). In addition, there was high reproducibility among the three independent biological replicates on 2-DE, i.e., $92.4,76.3$, and $76.7 \%$ for the $48 \mathrm{~h}, 84 \mathrm{~h}$ and $132 \mathrm{~h}$ gels, respectively (Additional file 1 : Table S1).

According to the changes in the patterns of protein abundance, the 88 DAPs were classified into three types: I, proteins with gradually decreased abundance or only observed at $48 \mathrm{~h}$; II, proteins with initially increased and gradually declined abundance or only observed at $84 \mathrm{~h}$; III, proteins with gradually increased abundance or only observed at $132 \mathrm{~h}$ (Fig. 5; Table 2).

Type I DAPs included heat shock proteins, stress proteins, storage proteins, protein biogenesis/degradationrelated proteins, oxidation-reduction proteins and carbohydrate biogenesis-related proteins (Additional file 5: Figure S2a). Type I DAPs were obviously crucial to the synthesis of proteins and building blocks and the energy metabolism required for cell division and expansion during mesocotyl growth. For example, the $16.9 \mathrm{kDa}$ class I heat shock protein 1 (spots 82, 83) and the Bowman-Birk type trypsin inhibitor (spots $68,76,77,84$ ) exhibited approximately 57 - and 40 -fold changes in abundance, respectively.

Type II DAPs mainly included oxidation-reduction proteins, increased carbohydrate biogenesis-related proteins and many cytoskeleton-related proteins (Additional file 5: Figure S2a). That is the biogenesis of the cell wall and cytoskeleton, and more energy continued to be necessary for the rapid growth of the mesocotyl. For example, actin (spots 39, 40), tubulin (spots 2, 3), calreticulin-2 (spot 7) and UDP-arabinopyranose mutase 3 (spot 50) showed increased abundance during the rapid growth period, and these proteins were all involved in cytoskeleton and cell wall biogenesis. Both V-ATPase subunits A and B (spots 5, 23 ), involved in cell wall loosening, and cytochrome c oxidase subunit 5b-2 (Spot 10), involved in mitochondrial electron transport, showed increased abundance during this period. Moreover, spot 37 was identified as the putative 2oxoglutarate-dependent dioxygenase AOP1, which shows 
$\begin{array}{ll}\text { A } & \text { B }\end{array}$
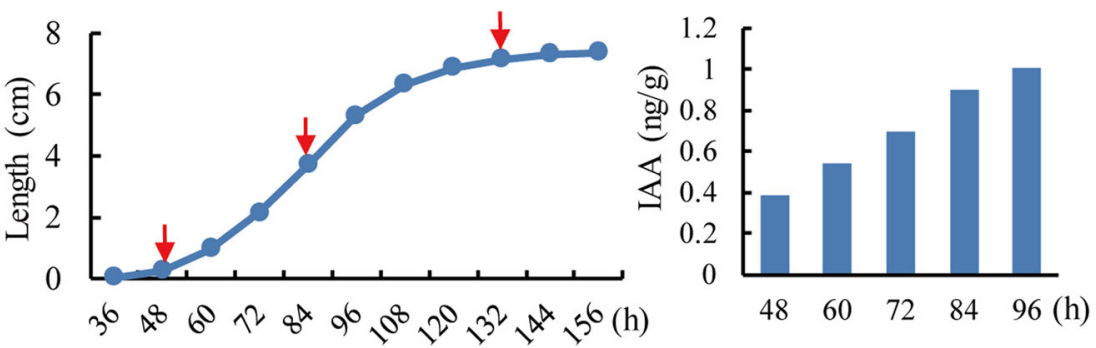

C

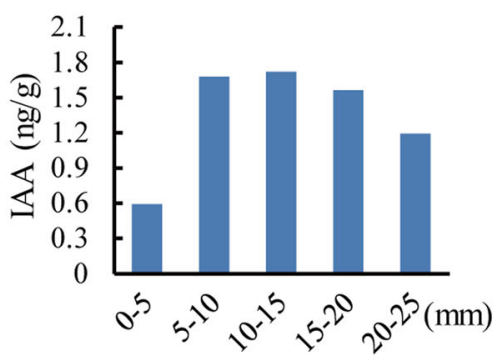

D
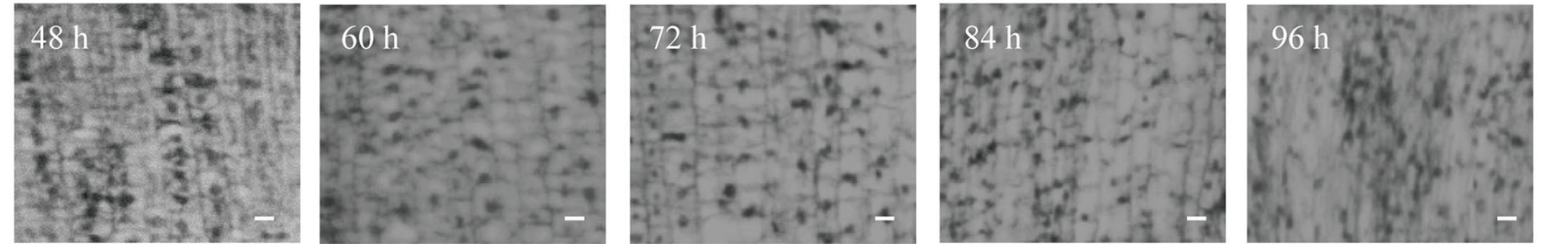

$\mathbf{E}$
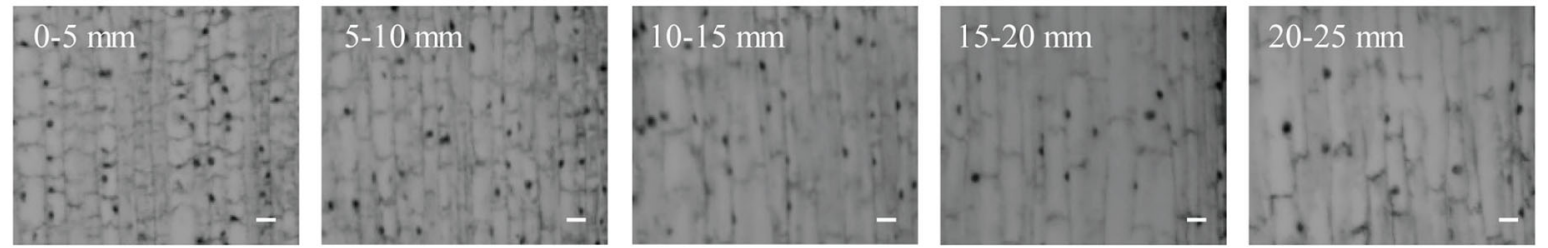

$\mathbf{F}$

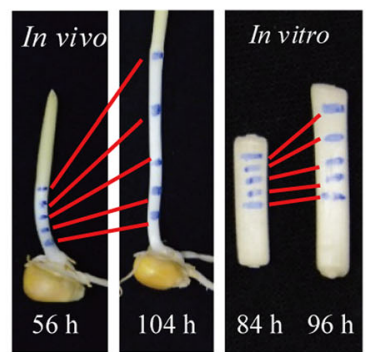

G

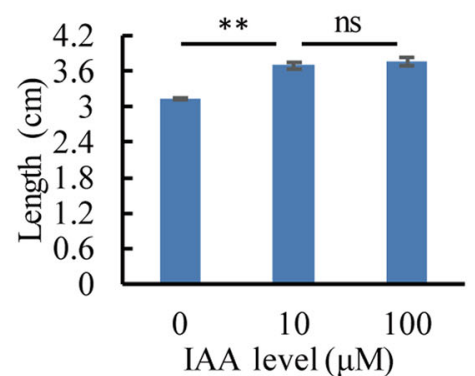

H

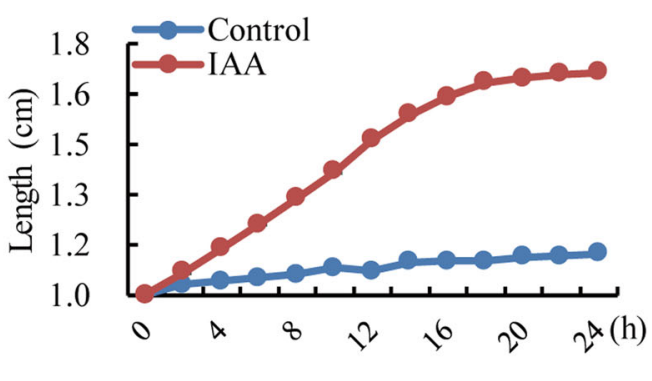

Fig. 2 Growth analysis of the etiolated mesocotyl. After imbibition for $12 \mathrm{~h}$, the maize seeds were germinated in darkness at $25^{\circ} \mathrm{C}$ for a week. a Growth curve of the mesocotyl in vivo. The arrows indicate the sampling time ( $48 \mathrm{~h}, 84 \mathrm{~h}$ and $132 \mathrm{~h}$ ) for proteomic analysis. b IAA content change with mesocotyl growth. IAA was determined per fresh weight. c IAA content in different parts of mesocotyl. The mesocotyls were sampled from 84-h-old etiolated seedlings. IAA was determined per fresh weight. $\mathbf{d}$ Light microscopy of the mesocotyl, showing the changes in cell morphology at the apical $5 \mathrm{~mm}$ part with mesocotyl growth. Bar $=10 \mu \mathrm{m}$. e Light microscopy of the mesocotyls, showing the changes in cell morphology at different parts of the 84-h-old mesocotyls. Bar $=10 \mu \mathrm{m}$. $\mathbf{f}$ Mesocotyl growth in vivo for $48 \mathrm{~h}$ and in vitro for $12 \mathrm{~h}$. The mesocotyls were marked to show the differential elongation of different parts. $\mathbf{g}$ IAA effect on mesocotyls grown in vitro for $12 \mathrm{~h}$. ${ }^{*}$ denotes $p<0.01$, ns stands for not significant. $\mathbf{h}$ Growth curve of the mesocotyl in vitro with or without $10 \mu \mathrm{M}$ IAA. The mesocotyl segments were sampled from 84h-old etiolated seedlings

indole-3-acetaldehyde oxidase activity in the cytoplasm. This protein accumulated in high abundance during the rapid growth period according to the change in IAA level.

Type III DAPs were mainly involved in protein biogenesis and degradation, cell wall biogenesis, carbohydrate biogenesis, cytoskeleton biogenesis and oxidation-reduction (Additional file 5: Figure S2a). Profilin (spot 20) and profilin-5 (spots 29,30 ) can bind to actin and affect the structure of the cytoskeleton. In particular, the abundance of cell wall-related proteins and carbohydrate biogenesis- 
Table 1 Analysis of maize mesocotyl growth

\begin{tabular}{|c|c|c|c|c|c|}
\hline \multicolumn{6}{|c|}{ A. Mesocotyl in vivo } \\
\hline Growth time & Fresh weight (mg) & Dry weight (mg) & RWC (\%) & Protein $\mathrm{mg} / \mathrm{g}$ dry weight & Cellulose (\%) (per dry weight) \\
\hline $48 \mathrm{~h}$ & $27.78 \pm 2.41^{\mathrm{a}}$ & $2.79 \pm 0.19^{a}$ & $90.86 \pm 0.33^{a}$ & $90.22 \pm 8.28^{a}$ & $31.04 \pm 3.41^{\mathrm{a}}$ \\
\hline $84 \mathrm{~h}$ & $115.93 \pm 2.10^{b}$ & $8.65 \pm 0.59^{b}$ & $93.06 \pm 0.36^{b}$ & $41.14 \pm 11.70^{b}$ & $40.65 \pm 0.79^{b}$ \\
\hline $132 \mathrm{~h}$ & $269.08 \pm 9.33 c$ & $22.24 \pm 0.88^{c}$ & $92.36 \pm 0.38^{b}$ & $38.48 \pm 4.30^{b}$ & $24.59 \pm 6.38^{c}$ \\
\hline \multicolumn{6}{|c|}{ B. Mesocotyl in vitro } \\
\hline Incubation time & Fresh weight (mg) & Dry weight (mg) & RWC (\%) & Protein mg/g dry weight & Cellulose (\%) (per dry weight) \\
\hline $\mathrm{Oh}$ & $32.78 \pm 0.52^{a}$ & $2.35 \pm 0.04^{\mathrm{a}}$ & $92.84 \pm 0.11^{\mathrm{a}}$ & $0.24 \pm 0.03^{\mathrm{a}}$ & No detection \\
\hline $12 \mathrm{~h},-\mathrm{IAA}$ & $38.23 \pm 0.50^{b}$ & $2.47 \pm 0.08^{a}$ & $93.53 \pm 0.18^{b}$ & $0.16 \pm 0.04^{a}$ & $23.93 \pm 1.52^{\mathrm{a}}$ \\
\hline $12 \mathrm{~h},+\mathrm{IAA}$ & $52.19 \pm 3.81^{c}$ & $2.73 \pm 0.02^{a}$ & $94.75 \pm 0.39^{c}$ & $0.15 \pm 0.02^{a}$ & $19.50 \pm 2.95^{b}$ \\
\hline
\end{tabular}

Assays were repeated at least three times. Values having different superscripts are significantly different at $p<0.01$

related proteins greatly changed. Xyloglucan endotransglucosylase/hydrolase (spots 22, 28, 88) and $\alpha$-1,4-glucanprotein synthase (spots 13,47 ) are involved in cell wall biogenesis, and peroxidase (spots 1, 15, 34, 43, 47) participated in decreased cell wall extensibility, and these proteins showed increased abundance during the slow growth period. Ribulose-phosphate 3-epimerase (spot 16), $\beta$-Dglucoside glucohydrolase (spot 46) and malate dehydrogenase (spot 49) are involved in cellular carbohydrate metabolic processes, and these activities are highly associated with organ growth and cell wall biogenesis, which is the most striking process during maize mesocotyl growth.

\section{Functional classification of DAPs with GO analysis}

The three types of DAPs were further classified using the Blast2GO software regarding biological process, molecular function and cellular component (Fig. 6). The top three common biological processes involving DAPs included cellular processes, metabolic processes and responses to stimuli. Diverse biological processes were initiated with mesocotyl growth, such as the negative regulation of biogenesis and signaling, which were exclusively associated with type III DAPs.

The major molecular functions of the DAPs included catalytic activity, binding and antioxidant activity, but each type of DAP involved specific functions (Additional file 5: Figure S2a). For example, type II and III DAPs shared structural molecule activities and transporter activities, whereas nutrient reservoir activity was specific to type III (storage proteins).

Regarding cellular components, the DAPs were most associated with the nucleus, microtubule, cytoplasm and cell wall, suggesting that these components were closely related to the growth of the maize mesocotyl. However, each DAP type had specific localizations, as shown by the subcellular location analysis (Additional file 5: Figure S2b).

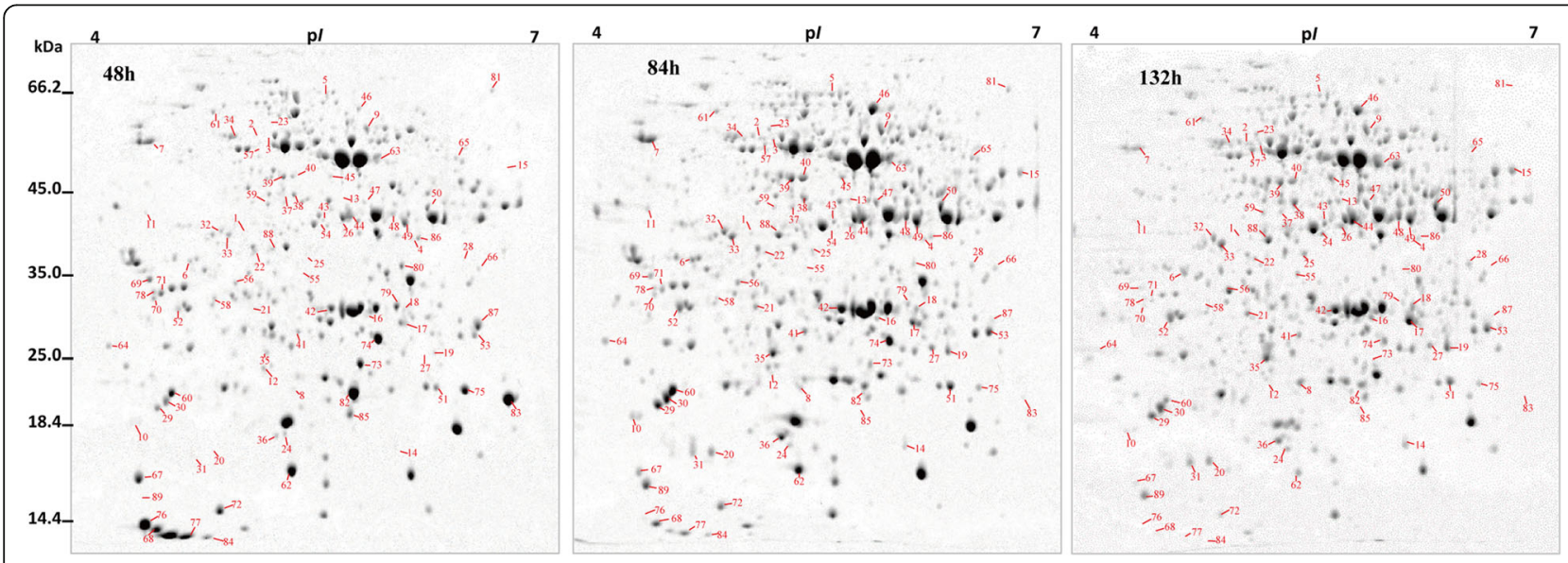

Fig. 3 The 2-DE analysis of mesocotyl growth. Mesocotyls were sampled from $48 \mathrm{~h}$-, $84 \mathrm{~h}$ - and $132 \mathrm{~h}$-old etiolated maize seedlings. Representative gels from three independent experiments are shown. The proteins $(600 \mu \mathrm{g})$ were resolved by IEF using $11 \mathrm{~cm}$ pH 4-7 IPG strips. SDS-PAGE was carried out on 12.5\% resolving gels. The proteins were visualized using CBB R350. Differentially abundant spots with at least 2-fold abundance changes are highlighted by numbers 
A

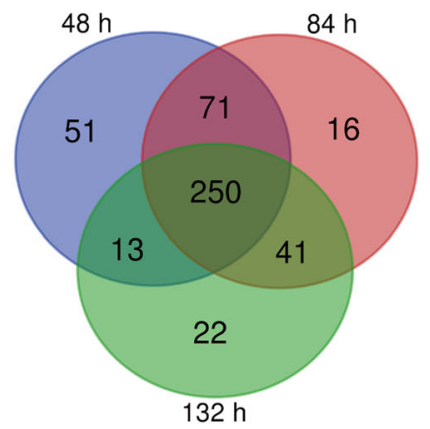

C

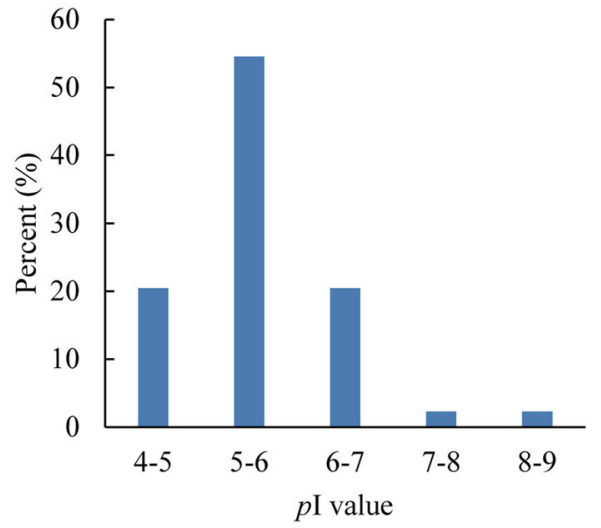

B

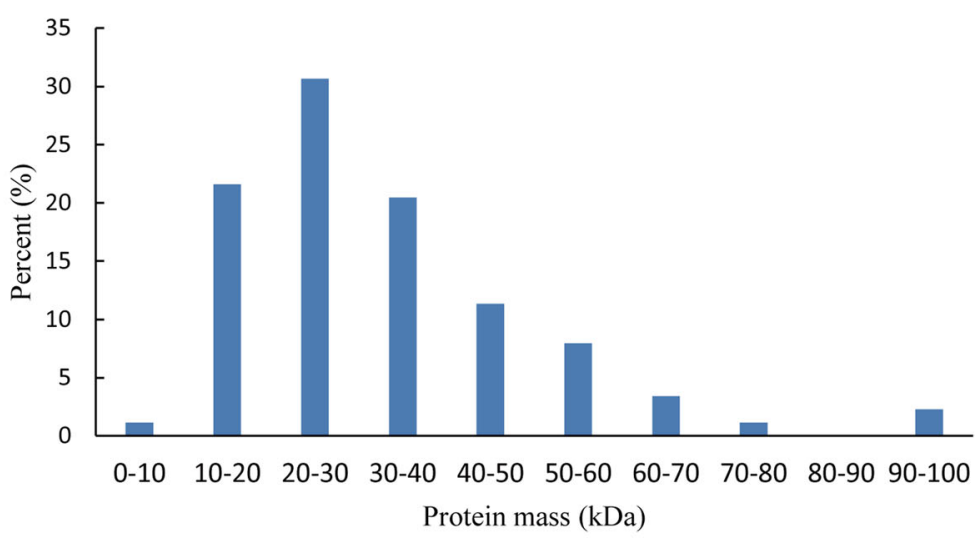

D

Fig. 4 Summary of DAPs identified in mesocotyls. a Venn diagrams of proteins resolved in 2-DE gels of the mesocotyls sampled at three time points. $\mathbf{b}$ MW distribution of DAPs. $\mathbf{c}$ p/ distribution of DAPs. $\mathbf{d}$ coverage (\%) of the matched sequences of DAPs

\section{Verification of DAPs associated with mesocotyl growth}

Nine DAPs of interest were analyzed with immunoblotting, RT-qPCR or enzyme activity assays. Immunoblot analysis revealed that actin and tubulin were highly accumulated at $84 \mathrm{~h}$ and $132 \mathrm{~h}$ during mesocotyl growth (Fig. 7a), which was consistent with the proteomic results. RT-qPCR showed that the mRNA expression of six DAPs occurred obviously earlier than the accumulation of corresponding proteins, which partly supported the proteomic results (Fig. 7b). Finally, POD isozyme activity increased with mesocotyl growth (Fig. 8), which was consistent with the abundance changes in this protein revealed by 2 -DE. Particularly, POD activity was higher at the lower part than at the upper part of the mesocotyl, which was in line with the fact that mesocotyl cells at the lower half matured earlier. Moreover, the POD isozyme activity of mesocotyl segments also increased in the presence of IAA.

\section{Discussion}

The maize mesocotyl is highly related to maize deepsowing tolerance [26-28]. This structure rapidly elongates during seed germination in the dark (in soil) and elevates the coleoptile (and the enclosed plumule) towards the soil surface. The elongating mesocotyl remains in soil throughout seed germination and seedling establishment. We showed here that mesocotyl growth was enhanced with depth (Fig. 1) by mimicking natural seed germination. Regardless of depth, the etiolated mesocotyl never penetrated the surface of the soil. Therefore, studying the growth of the etiolated mesocotyl has practical significance.

Numerous studies have shown that auxin promotes the growth of the maize mesocotyl. In the classical acidgrowth theory, auxin activates the plasma-membrane $\mathrm{H}^{+}$-ATPase, resulting in membrane hyperpolarization, apoplastic acidification and acid-dependent cell wall loosening, which in turn permits cell growth $[29,30]$. In 


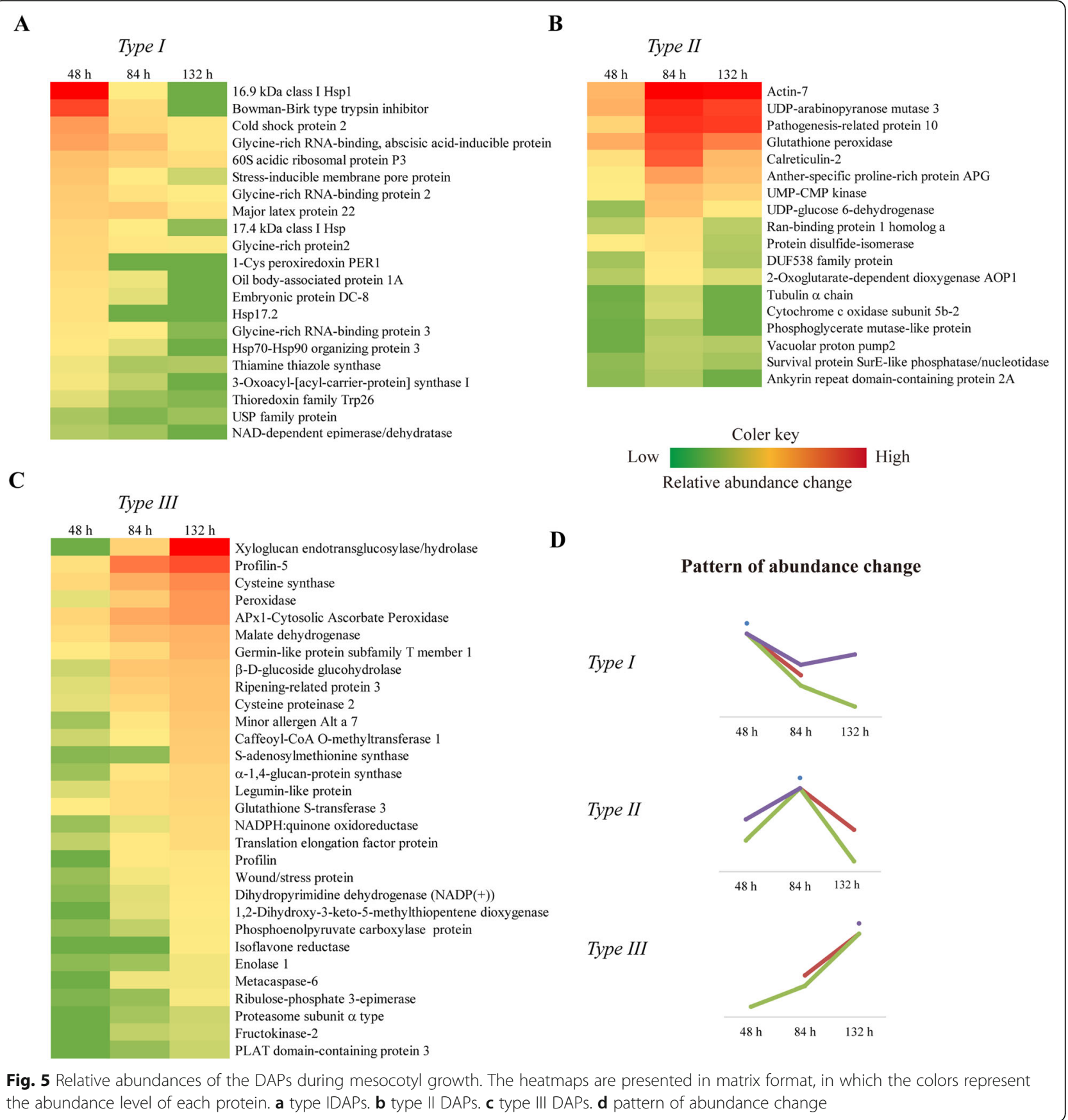

our study, changes in the content of IAA in etiolated mesocotyls at different growth periods coincided with the mesocotyl growth curve (Fig. 2b) and varied in different zones of the mesocotyl (Fig. 2c). Mesocotyl segments grew quickly in the first $24 \mathrm{~h}$ in the presence of IAA and slowed down until its growth was ceased. This effect was probably due to a loss of turgor pressure caused by the dilution of vacuolar contents [31] or due to reaching the final sizes of mesocotyl cells [32]. We also found that the cellulose content of mesocotyl segments grown in vitro was decreased by exogenous IAA
[33] or gibberellin [34]. Similarly, almost all protein spots in the 2-DE gels declined in abundance for mesocotyl segments grown in vitro (data not shown), i.e., lacking net protein synthesis, as previously reported [35]. This finding could be explained by the fact that in intact tissues, the balance between synthesis and hydrolysis is actively maintained, whereas in excised tissues, the synthesis is greatly slowed or inhibited, and hydrolytic events predominate.

We found that there was an obvious change in the protein patterns with the growth of the maize mesocotyl 
Table 2 Summary of the DAPs associated to mesocotyl growth in maize

\begin{tabular}{|c|c|c|c|}
\hline Spot & UniProtKB accession & Protein & $\begin{array}{l}\text { Function or biological } \\
\text { process involved }\end{array}$ \\
\hline \multicolumn{4}{|l|}{ Type I DAPS } \\
\hline 12 & K7V2N6 & USP family protein & Response to stress \\
\hline 62 & P10979 & $\begin{array}{l}\text { Glycine-rich RNA-binding, } \\
\text { ABA-inducible protein }\end{array}$ & \\
\hline 73 & B4F976 & $17.4 \mathrm{kDa}$ class I HSP & \\
\hline 74 & COPLI2 & Cold shock protein 2 & \\
\hline 75 & A0A1D6MRR5 & $\begin{array}{l}\text { Stress-inducible membrane } \\
\text { pore protein }\end{array}$ & \\
\hline 81 & A0A1D6HEP0 & $\begin{array}{l}\text { Hsp70-Hsp90 organizing } \\
\text { protein } 3\end{array}$ & \\
\hline 82,83 & B6SIX0 & 16.9 kDa class I HSP 1 & \\
\hline 85 & A0A1D6MLV9 & HSP 17.2 & \\
\hline 58 & B4FPP1 & Thioredoxin family Trp26 & $\begin{array}{l}\text { Cell redox homeostasis, } \\
\text { defense response }\end{array}$ \\
\hline 59 & B4G015 & Thiamine thiazole synthase & Thiamine biosynthesis \\
\hline 60 & Q19VG6 & Major latex protein 22 & $\begin{array}{l}\text { abscisic acid-activated } \\
\text { signaling pathway, } \\
\text { defense response }\end{array}$ \\
\hline 65 & K7V9P7 & $\begin{array}{l}\text { 3-Oxoacyl-[acyl-carrier-protein] } \\
\text { synthase I chloroplastic }\end{array}$ & Fatty acid biosynthesis \\
\hline 66 & A0A1D6L9Y9 & $\begin{array}{l}\text { NAD-dependent } \\
\text { epimerase/dehydratase }\end{array}$ & $\begin{array}{l}\text { Colanic acid and lipopolysaccharide } \\
\text { biosynthesis }\end{array}$ \\
\hline 67,89 & $\begin{array}{l}\text { A0A1D6LNJ7 } \\
\text { B4G1B3 }\end{array}$ & 605 acidic ribosomal protein P3 & Structural constituent of ribosome \\
\hline $68,76,77,84$ & A0A1D6MM79 & Bowman-Birk type trypsin inhibitor & $\begin{array}{l}\text { Serine-type endopeptidase inhibitor } \\
\text { activity }\end{array}$ \\
\hline 69,71 & A0A1D6IV87 & Glycine-rich protein2 & Mitochondrial mRNA modification \\
\hline 72 & B6SIF0 & Glycine-rich RNA-binding protein 2 & \\
\hline 70,78 & A0A1D6MXZ7 & Glycine-rich RNA-binding protein 3 & \\
\hline 79 & B4FFZ9 & Oil body-associated protein $1 \mathrm{~A}$ & Storage protein \\
\hline 80,86 & $\begin{array}{l}\text { B6SGN7, } \\
\text { A0A1D6JQ00 }\end{array}$ & Embryonic protein DC-8 & \\
\hline 87 & A2SZW8 & 1-Cys peroxiredoxin PER1 & Cell redox homeostasis \\
\hline \multicolumn{4}{|l|}{ Type /I DAPs } \\
\hline 2,3 & $\begin{array}{l}\text { A0A1D6GIG4 } \\
\text { COPKT5 }\end{array}$ & Tubulin a chain & Structural constituent of cytoskeleton \\
\hline 39,40 & A0A1D6FW13, A0A1D6EHT1 & Actin-7 & \\
\hline 4 & A0A1D6EG37 & Phosphoglycerate mutase & Carbohydrates metabolism \\
\hline 5,23 & A0A1D6P248 & Vacuolar proton pump2 & ATP metabolic process \\
\hline 6 & A0A1D6JZE5 & Ran-binding protein 1 & $\begin{array}{l}\text { Intracellular transport, positive } \\
\text { regulation of GTPase activity }\end{array}$ \\
\hline 7 & A0A1D6EN35 & Calreticulin-2 & Protein folding \\
\hline 8 & B4FMB1 & DUF538 family protein & Uncharacterized \\
\hline 9 & $B 7 Z Y X 8$ & UDP-glucose 6-dehydrogenase & Glycosaminoglycan biosynthesis \\
\hline 10 & K7 V763 & Cytochrome c oxidase subunit 5b-2 & Mitochondrial electron transport \\
\hline 11 & B4G137 & $\begin{array}{l}\text { Ankyrin repeat domain-containing } \\
\text { protein } 2 \mathrm{~A}\end{array}$ & Protein targeting to chloroplast \\
\hline 24,36 & Q29SB6 & Pathogenesis-related protein 10 & Response to stress \\
\hline 32 & B4F9E3 & Anther-specific proline-rich protein APG & $\begin{array}{l}\text { Hydrolase activity, acting on } \\
\text { ester bonds }\end{array}$ \\
\hline 34 & A0A1D6G329 & Survival protein SurE-like & Hydrolase activity \\
\hline
\end{tabular}


Table 2 Summary of the DAPs associated to mesocotyl growth in maize (Continued)

\begin{tabular}{|c|c|c|c|}
\hline Spot & UniProtKB accession & Protein & $\begin{array}{l}\text { Function or biological } \\
\text { process involved }\end{array}$ \\
\hline & & phosphatase/nucleotidase & \\
\hline 37 & B4FN73 & $\begin{array}{l}\text { 2-Oxoglutarate-dependent } \\
\text { dioxygenase AOP1 }\end{array}$ & Auxin catabolic process \\
\hline 41 & A0A1D6QDC6 & UMP-CMP kinase & Nucleotide biosynthesis \\
\hline 50 & B4G039 & UDP-arabinopyranose mutase 3 & $\begin{array}{l}\text { UDP-L-arabinose metabolic process, } \\
\text { plant-type cell wall biogenesis }\end{array}$ \\
\hline 51 & Q6JAH6 & Glutathione peroxidase & Cell redox homeostasis \\
\hline 61 & A0A1D6F5C2 & Protein disulfide-isomerase & \\
\hline \multicolumn{4}{|l|}{ Type III DAPs } \\
\hline $1,15,33$ & A0A1D6E530, B6THU9 & Peroxidase & Response to stress \\
\hline 14 & C4J9RO & PLAT domain-containing protein 3 & \\
\hline 31 & K7U5W7 & Wound/stress protein & \\
\hline 42 & B6TM55 & APx1-cytosolic ascorbate peroxidase & \\
\hline 13,47 & B4FQX1 & a-1,4-glucan-protein synthase & $\begin{array}{l}\text { UDP-L-arabinose metabolic process, } \\
\text { plant-type cell wall biogenesis }\end{array}$ \\
\hline 16 & A0A1D61841 & Ribulose-phosphate 3-epimerase & Carbohydrate metabolic process \\
\hline 49 & A0A1R3MB28 & Malate dehydrogenase & \\
\hline 46 & P49235 & $\beta$-D-glucoside glucohydrolase & \\
\hline 29,30 & Q9FR39 & Profilin-5 & \\
\hline 17 & B4FRS8 & $\begin{array}{l}\text { Germin-like protein subfamily } T \\
\text { member } 1\end{array}$ & $\begin{array}{l}\text { Manganese ion binding, nutrient } \\
\text { reservoir activity }\end{array}$ \\
\hline 18 & A0A1D6N0U0 & NADPH:quinone oxidoreductase & Oxidation-reduction process \\
\hline 19 & B4FWD0 & Minor allergen Alt a 7 & \\
\hline 20 & A0A1D6GCC8 & Profilin & $\begin{array}{l}\text { Regulation of actin cytoskeleton } \\
\text { organization }\end{array}$ \\
\hline 21 & A0A1D6JPD5 & $\begin{array}{l}\text { 1,2-Dihydroxy-3-keto-5-methylthiopentene } \\
\text { dioxygenase }\end{array}$ & Methionine metabolic process \\
\hline $22,28,88$ & B4FTH5, B4FHS5, B6T2W7 & Xyloglucan endotransglucosylase/hydrolase & $\begin{array}{l}\text { Cell wall biogenesis, xyloglucan } \\
\text { metabolic process }\end{array}$ \\
\hline 25 & B6TAJ3 & Proteasome subunit a type & Proteasomal protein catabolic process \\
\hline 26 & A0A1D6LDR6 & Fructokinase-2 & Carbohydrate metabolic process \\
\hline 27 & A0A1D6N9H5 & Metacaspase-6 & Cysteine-type peptidase activity \\
\hline 35 & A0A1D6GNR3 & Ripening-related protein 3 & Defense response to fungus \\
\hline 38 & A0A1D6GCC4 & $\begin{array}{l}\text { Translation elongation factor } \\
\text { family protein }\end{array}$ & Translation elongation factor activity \\
\hline 43 & A0A1D6ECS1 & $\begin{array}{l}\text { Phosphoenolpyruvate carboxylase } \\
\text { family protein }\end{array}$ & $\begin{array}{l}\text { Carbon fixation in CAM and C4 } \\
\text { organisms }\end{array}$ \\
\hline 44 & B8A377 & Cysteine synthase & Cysteine biosynthetic \\
\hline 45 & B4FZU9 & $\begin{array}{l}\text { Dihydropyrimidine dehydrogenase } \\
(\mathrm{NADP}(+))\end{array}$ & $\begin{array}{l}\text { Cellular response to nitrogen levels, } \\
\text { thymine catabolic process, uracil } \\
\text { catabolic process }\end{array}$ \\
\hline 48 & Q84TL7 & Legumin-like protein & nutrient reservoir activity \\
\hline 52 & A0A1D615B2 & Cysteine proteinase 2 & Cysteine-type peptidase activity \\
\hline 53 & B4FK84 & Glutathione S-transferase 3 & Glutathione metabolic process \\
\hline 54 & B4FD74 & Isoflavone reductase-like1 & $\begin{array}{l}\text { 2'-hydroxyisoflavone reductase } \\
\text { activity, defense response }\end{array}$ \\
\hline 56 & B6UF45 & Caffeoyl-CoA O-methyltransferase 1 & Feruloylated polysaccharides synthesis \\
\hline 57 & A0A1D6NVW3 & Enolase 1 & Glycolytic process \\
\hline 63 & B4FIE9 & $\begin{array}{l}\text { S-adenosylmethionine } \\
\text { synthase }\end{array}$ & $\begin{array}{l}\text { S-adenosylmethionine biosynthetic } \\
\text { process, one-carbon metabolic process }\end{array}$ \\
\hline
\end{tabular}




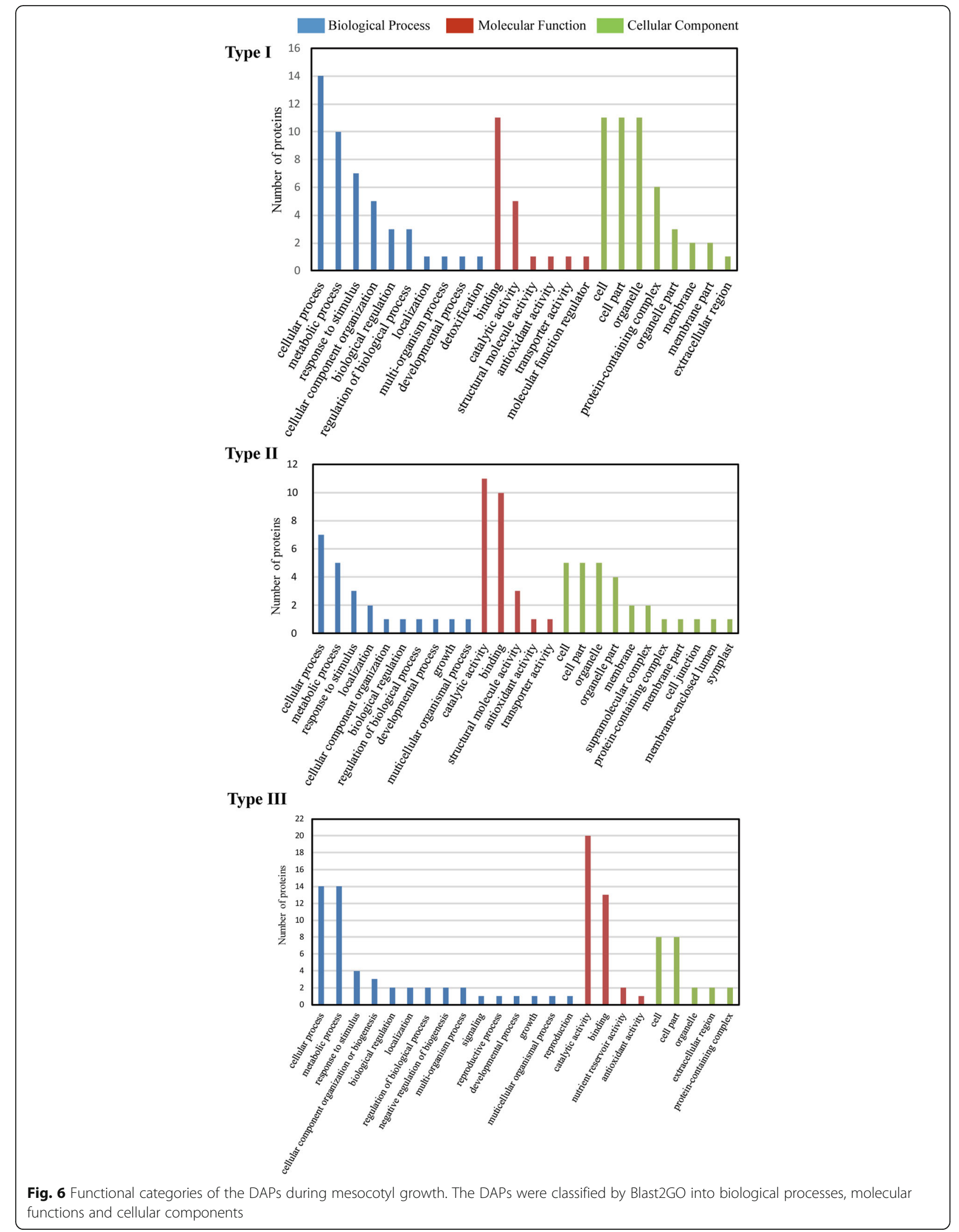


A

Tubulin

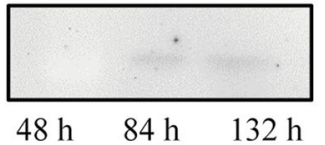

B

Putative ATPase

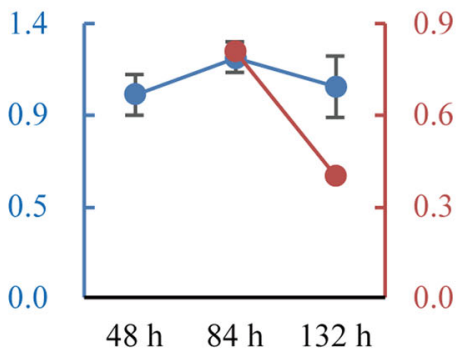

Xyloglucan endotransglucosylase/hydrolase

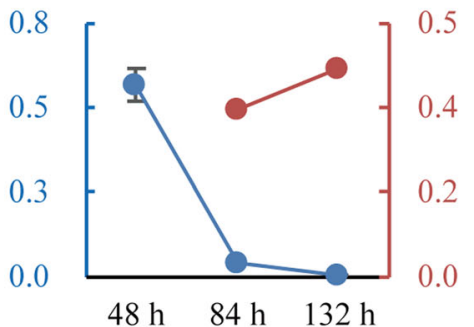

UDP-arabinopyranose mutase 3

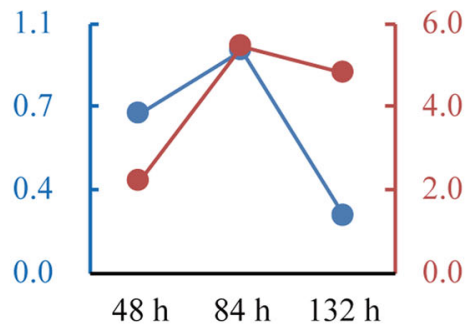

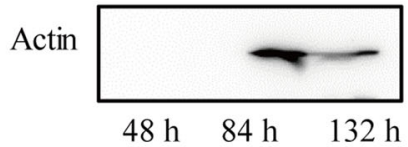

$\alpha$-1,4-glucan-protein synthase

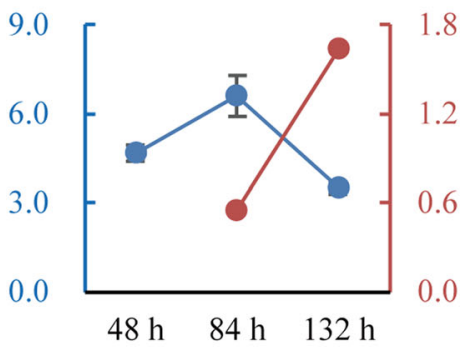

Cysteine synthase

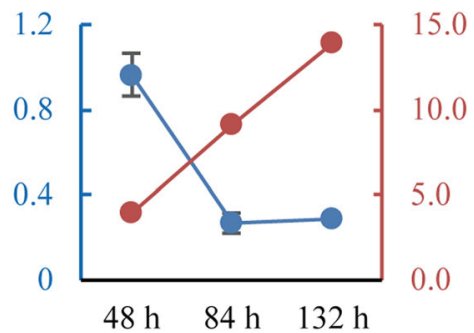

Cysteine proteinase 2

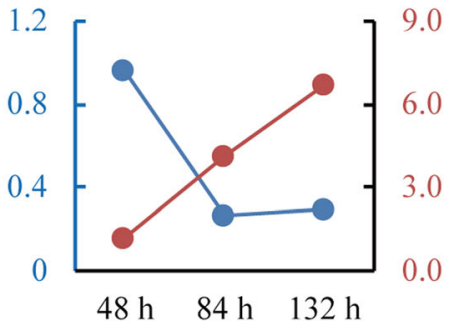

Fig. 7 Verification of the selected DAPs during mesocotyl growth. a Immunoblot detection of actin and tubulin. $\mathbf{b}$ RT-qPCR of the mRNAs of six DAPs. Red and blue lines represent the levels of proteins and mRNAs, respectively

(Figs. 4, 5, 6 and 7); that is, the mesocotyl at different periods had a distinct set of DAPs. To obtain reliable proteomic data, the DAPs identified here by Mascot search have manually been checked by referring to its MW and $\mathrm{p} I$ in 2-D gels and by searching the nonredundant database of UniProtKB for each possible DAPs. Due to the inherent limitations of 2-DE, the DAPs identified here may represent a small number of proteins in the mesocotyl proteome. Using a more robust gel-free (e.g., iTRAQ-based) proteomic analysis will reveal comprehensive proteome changes during maize mesocotyl growth.
In 48-h-old mesocotyls, most DAPs (79\%) were heat shock proteins, stress proteins and proteins related to protein biogenesis and degradation, and the other proteins $(21 \%)$ were storage proteins, oxidation/reduction proteins and carbohydrate biogenesis-related proteins. These DAPs were mainly involved in cellular process, metabolic process and response to stimulus (Fig. 6, Additional file 5: Figure $\mathrm{S} 2 \mathrm{a}$ ) and required for protein and carbohydrate metabolism to prepare raw materials and energy at the initial growth of the maize mesocotyl. Particularly, the $60 \mathrm{~S}$ acidic ribosomal protein P3 (spots 


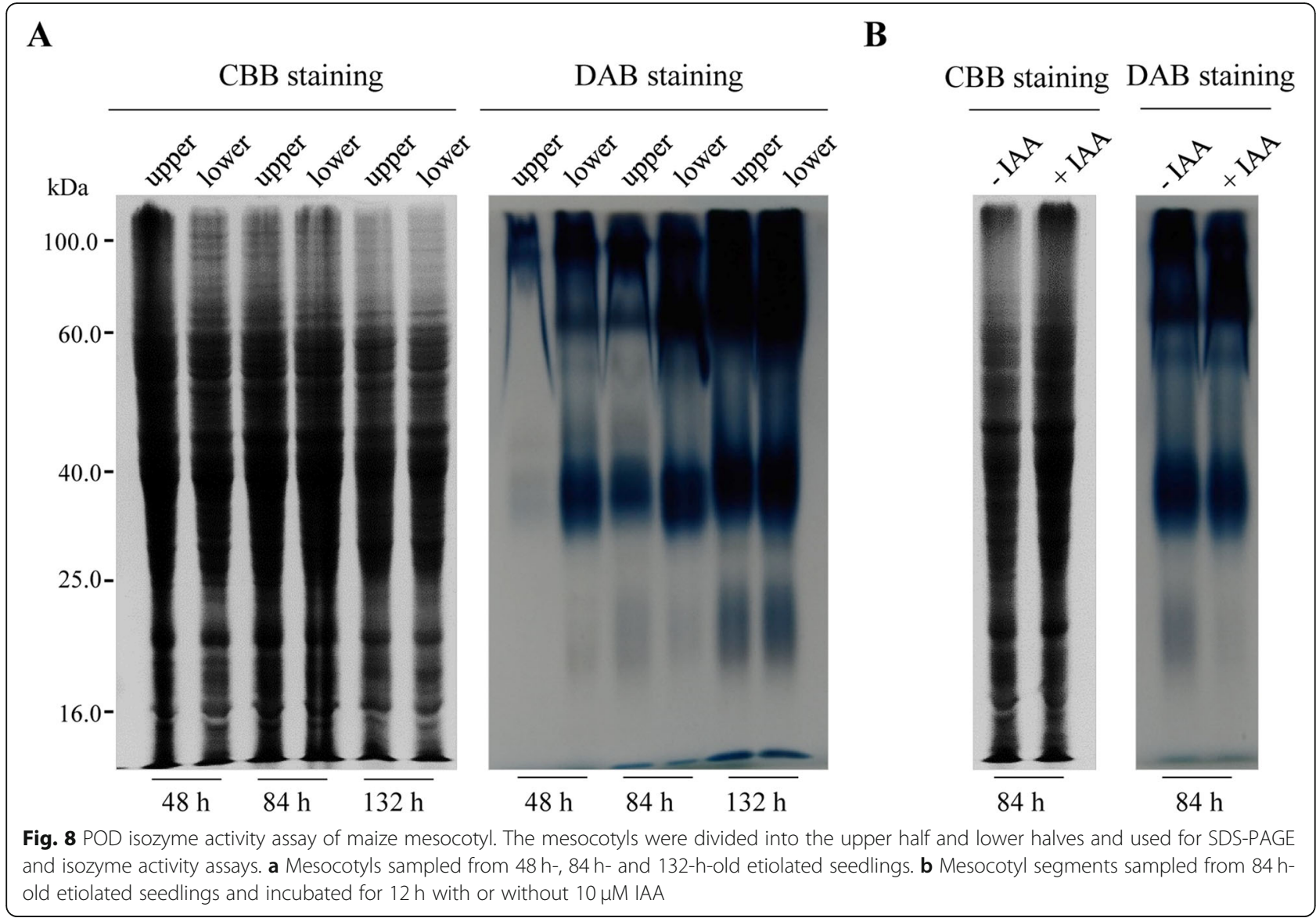

$67,89)$ of the structural constituent of ribosome existed in highest abundance during the initial period than in the later periods, and its decreasing abundance was consistent with the increased activity of ribonuclease during maize mesocotyl growth [35].

In 84-h-old mesocotyls, the proportions of carbohydrate biosynthesis-related proteins, oxidation/reduction enzymes and cytoskeleton proteins among the DAPs significantly increased (Fig. 6, Additional file 5: Figure S2a). Cell growth at the tip of the etiolated mesocotyl is dependent on vacuole enlargement and the massive flux of endoplasmic reticulum (ER) and Golgi vesicles. The expression of V-ATPase genes was found to be positively correlated with cellular growth [11]. In rye, the cessation of coleoptile growth was associated with the downregulation of the subunit E of the V-ATPase [29]. Water flow into the expanding vacuole is driven by ion accumulation, which in turn is energized by the vacuolar $\mathrm{H}^{+}$ATPase (V-ATPase) [29]. We found here that V-ATPase (spots 5 and 23 corresponding to catalytic subunits A and $\mathrm{B}$, respectively) was highly accumulated during the rapid growth period of the mesocotyl. The microtubule and actin cytoskeleton mediates cell growth, division and morphogenesis [36]. We found that actin-7, existing in four spots (2, 3, 39 and 40), increased in abundance during the rapid growth period of the mesocotyl. Tubulin was also observed to highly accumulate in the rice coleoptile under anoxic conditions [37]. Moreover, cytochrome c oxidase subunit 5b-2 (spot 10), which is involved in mitochondrial electron transport, had a higher abundance during this period. However, a previous study showed that red light inhibited mesocotyl growth in darkgrown maize seedlings, along with the decreased activity of cytochrome reductase but without a detectable change in the activity of cytochrome oxidase [9].

The cell wall is a dynamic structure that consists of an intertwined network of polysaccharides, lignin, and proteins $[33,38]$. Cellulose is the most abundant component in the walls of growing cells. Cellulose consists of a collection of $\beta-1,4$-linked glucan chains that interact with each other via hydrogen bonds to form a crystalline microfibril [39]. We found here that the cellulose content reached a maximum during the rapid growth period of the mesocotyl, indicating quick wall synthesis, and then decreased thereafter. Cellulose biosynthesis involves a large multisubunit complex consisting of at least three different cellulose synthase enzymes [40]. The complex localized in the plasma membrane as a rosette structure that transfers Glc 
from cytosolic UDP-Glc to produce multiple extracellular glucan chains that eventually coalesce into a cellulose microfibril [33]. Some cellulose synthase-like genes $(\mathrm{ZmCSL})$ are regulated by light, whose expression changes in parallel with the growth rate of the mesocotyl [41]. Consistent with the changes in cellulose content (Fig. 3), we found that UDP-glucose 6-dehydrogenase (spot 9) accumulated at higher abundance during the rapid growth period of the mesocotyl and then gradually decreased.

In 132-h-old mesocotyls, cell wall-related proteins remarkably increased in number (taking up 14\% of type III DAPs) (Fig. 6, Additional file 5: Figure S2a). Mesocotyl growth is closely related to cell wall extensibility or cell wall "loosening", driven by the pressure of the protoplasm [1]. Wall extensibility can be accomplished by one or more wall-localized enzymes that catalyze the formation or breakage of cell wall bonds, especially the hydrolysis of cell wall glucans, in particular xyloglucan [34, 42]. Accordingly, we found that xyloglucan endoglucosylase/hydrolases (spots 22, 28, 88) began to accumulate during the rapid growth period and significantly increased with mesocotyl growth.

Moreover, hydrogen peroxide plays a key role in the modulation of extension growth by decreasing wall extensibility through the peroxidase-mediated oxidative cross-linking of cell wall glycoproteins and polysaccharides [23, 43]. Red light suppressed the mesocotyl growth of maize, resulting in a $40 \%$ increase in the level of peroxidase in mesocotyl walls [44]. Here, we found that peroxidase, existing in multiple spots $(1,15,34,43,47)$ during the slow growth period, was increased in both abundance and enzyme activity, especially at the maturation part of the mesocotyl (Fig. 6). This result was consistent with previous results showing a negative correlation between wall peroxidase activity and wall growth $[45,46]$.

Additionally, the mRNA levels of six DAPs were partly correlated with protein abundance, and their gene expression occurred earlier than their protein accumulation (Fig. 7). The transcript/protein discordance has been well documented in maize [47], possibly because the protein life-time is far shorter than mRNA life-time and/or these transcripts are not fully translated.

\section{Conclusions}

Until now, there is still a lack of omics studies on the growth of maize mesocotyl. In this study, we explored maize mesocotyl growth in vivo and in vitro at physiological and proteomic levels. The growth of maize mesocotyl, accompanied by changes in IAA content and cell wall cellulose, contributed greatly to seed germination and early seedling establishment. The protein patterns on 2-D gels differed with mesocotyl growth, and a total of 88 DAPs were associated with etiolated mesocotyl growth. At different periods of mesocotyl growth, a specific set of DAPs were involved in various biological processes and underlie the cellular and physiological activities. These results provide new information for understanding the growth of maize mesocotyl and the cultivation of maize mesocotyl with deep-sowing tolerance.

\section{Methods}

\section{Plant material and growth conditions}

Maize hybrid Zhengdan 958, currently grown widely in China, was used in the present study. Mature maize seeds were purchased from the Henan Qiule Seed Industry Science and Technology Company, Ltd. (Zhengzhou, China). The seeds were surface-sterilized with $0.1 \%$ sodium hypochlorite and rinsed thoroughly. After imbibition for $12 \mathrm{~h}$ in water, the imbibed seeds were germinated in growing medium (Pindstrup Substrate, 0-6 mm, pH 6.0, Pindstrup Mosebrug A/S, Denmark) in plastic pots $(25 \times 19 \times 30 \mathrm{~cm})$ at sowing depths of $5 \mathrm{~cm}, 10 \mathrm{~cm}$ and 15 $\mathrm{cm}$, respectively. The pots were well watered and placed in a greenhouse with a photoperiod of $16 \mathrm{~h}$ light (80-100 $\left.\mu \mathrm{E} \mathrm{m}{ }^{-2} \mathrm{~s}^{-1}, 28^{\circ} \mathrm{C}\right)$ and $8 \mathrm{~h}$ dark $\left(22^{\circ} \mathrm{C}\right)$. After 14 days, the seedling emergence rate, mesocotyl and coleoptile length were measured. All of the above experiments were carried out with at least three independent biological replicates.

Additionally, the imbibed seeds were germinated on wet papers in darkness at $25^{\circ} \mathrm{C}$ for a week. For mesocotyl growth in vitro, $10 \mathrm{~mm}$ segments were excised under dim green light from the apical region of the dark-grown $84 \mathrm{~h}$ old mesocotyls downwards. Twenty segments were incubated for $24 \mathrm{~h}$ in the dark $\left(25^{\circ} \mathrm{C}\right)$ in MS medium ( $\left.\mathrm{pH} 6.0\right)$ plus $1 \%$ sucrose, with or without IAA $(10 \mu \mathrm{M}$ or $100 \mu \mathrm{M})$ [48]. The mesocotyls grown in vivo or in vitro were sampled at different times for various analyses.

\section{Physiological and biochemical analysis}

For biomass and moisture content assays, the fresh and dry weights (after drying at $60^{\circ} \mathrm{C}$ for $48 \mathrm{~h}$ ) of mesocotyl samples were determined on a precision balance, and the RWC was calculated [49].

The cellulose content was determined using the anthrone-sulfuric acid method [50]. The mesocotyl sample $(0.02 \mathrm{~g}$ dry weight) was hydrolyzed in $6 \mathrm{ml} 60 \%$ $\mathrm{H}_{2} \mathrm{SO}_{4}$ for $30 \mathrm{~min}$, and then $2 \mathrm{ml}$ of the hydrolysate was mixed with $0.5 \mathrm{ml} 2 \%$ anthrone reagent and $5 \mathrm{ml} \mathrm{H}_{2} \mathrm{SO}_{4}$ and incubated for $10 \mathrm{~min}$. After centrifugation of the mixture, the absorbance at $620 \mathrm{~nm}$ was read, with cellulose as a standard.

The levels of IAA in maize mesocotyls were quantified by high-performance liquid chromatography-tandem mass spectrometry (HPLC-MS/MS) [51]. Mesocotyl samples (1.0 g fresh weight) were ground in a mortar with liquid $\mathrm{N}_{2}$ and then homogenized in $10 \mathrm{ml}$ isopropanol/hydrochloric acid buffer. The extract was shaken at $4{ }^{\circ} \mathrm{C}$ for 30 
min, and then $20 \mathrm{ml}$ dichloromethane was added and shaken at $4{ }^{\circ} \mathrm{C}$ for $30 \mathrm{~min}$. After centrifugation at 13,000 rpm for $5 \mathrm{~min}$ at $4{ }^{\circ} \mathrm{C}$, the organic phase was extracted and dried under $\mathrm{N}_{2}$. The resulting dry pellets were resuspended in $200 \mu \mathrm{l}$ methanol plus $0.1 \%$ methane acid and filtered with a $0.22-\mathrm{mm}$ filter membrane. The filtrate was used for HPLCMS/MS with a ZORBAXSB-C18 (Agilent Technologies) column $(2.1 \times 150 ; 3.5 \mathrm{um})$ at $30^{\circ} \mathrm{C}$. The sample injection volume was $2 \mu \mathrm{l}$. The mobile phase: $\mathrm{A}: \mathrm{B}=$ (methanol/0.1\% formic acid): (water $/ 0.1 \%$ formic acid); elution gradient: 0$2 \mathrm{~min}, \mathrm{~A}=20 \% ; 2-14 \mathrm{~min}$, An increased to $80 \%$; $14-15$ $\min , A=80 \%$; $15.1 \mathrm{~min}$, A decreased to $20 \%$; $15.1-20 \mathrm{~min}$, $\mathrm{A}=20 \%$. The MS conditions were as follows: the pressures of the air curtain, nebulizer, and aux gas were 15,65 , and $70 \mathrm{psi}$, respectively; the spray voltage was $4500 \mathrm{~V}$; and the atomizing temperature was $400^{\circ} \mathrm{C}$.

\section{Light microscopy}

Mesocotyl samples were fixed in the FAA solution for $48 \mathrm{~h}$, maintained in $50 \%$ ethanol for $24 \mathrm{~h}$ and then dehydrated in a series of alcohols and embedded in paraffin wax. Serial sections were longitudinally cut along the tangential direction with a sliding microtome at 10 - to $15-\mu \mathrm{m}$ thick, stained with safranin-fast green, and mounted in Canada balsam [52]. Ten to twelve slides were prepared from each sample. The specimens were observed using a Phoenix PH50 light microscope and recorded and digitized using ToupView $\times$ 86 software (ToupTek Photonics; China).

\section{Protein extraction and quantitation}

Mesocotyl proteins were extracted as described previously [53]. The mesocotyls were pulverized in a mortar and pestle with liquid $\mathrm{N}_{2}$ and then homogenized with cold acetone plus $5 \mathrm{mM}$ DTT. The acetone-washed dry tissue pellets were subjected to protein extraction in an SDS buffer containing 1\% SDS, $0.1 \mathrm{M}$ Tris- $\mathrm{HCl}$ (pH 6.8), $2 \mathrm{mM}$ EDTA-Na $2,20 \mathrm{mM}$ DTT and $2 \mathrm{mM}$ PMSF. The resulting protein extract was precipitated with an equal volume of cold $20 \% \mathrm{TCA} /$ acetone. The protein precipitates were washed twice with $80 \%$ acetone, air-dried and dissolved in Laemmli SDS buffer for SDS-PAGE or in 2$\mathrm{DE}$ rehydration solution containing $7 \mathrm{M}$ urea, $2 \mathrm{M}$ thiourea, 2\% CHAPS, $20 \mathrm{mM}$ DTT, 0.5\% IPG buffer (pH 4-7, GE Healthcare) for isoelectric focusing (IEF) [54]. Alternatively, the protein precipitates were dissolved in the 2-DE rehydration solution without the IPG buffer to avoid interference with the assay [55]. After protein quantitation, IPG buffer was supplemented into protein samples to a final concentration of $0.5 \%$ for IEF.

SDS-PAGE, immunoblotting and peroxidase (POD) activity staining

SDS-PAGE was performed on a Laemmli gel system (5\% stacking gel and $12.5 \%$ resolving gel). After electrophoresis, the gels of mesocotyl proteins were stained with $0.1 \%$ Coomassie brilliant blue (CBB) R-350 overnight and destained in $7 \%$ acetic acid until a clear background was obtained. The gels were photographed using a DSLR camera (Nikon D7000) in automatic mode.

For immunoblotting, the protein gels were electrophoretically transferred onto a polyvinylidene difluoride membrane (Hybond-P, GE healthcare) in a transfer buffer $(20 \%$ $\mathrm{v} / \mathrm{v}$ methanol, $48 \mathrm{mM}$ Tris, $39 \mathrm{mM}$ glycine) for $20 \mathrm{~min}$ at $15 \mathrm{~V}$ on a semi-dry electrophoretic transfer cell system (Trans-Blot, Bio-Rad, USA). After incubation in 5\% skimmed milk in TBST buffer $(50 \mathrm{mM}$ Tris- $\mathrm{HCl}, \mathrm{pH} 7.5$, $0.15 \mathrm{M} \mathrm{NaCl}, 0.1 \%$ Tween-20) for $1 \mathrm{~h}$, the membrane was incubated with anti-actin and anti-tubulin polyclonal antibodies (A01050, A01030, Abbkine; USA) in TBST buffer (1:5000 dilution) for $1 \mathrm{~h}$, respectively, and subsequently incubated with POD-conjugated goat anti-mouse IgG (CW0102S, CWBIO, China) (1:5000 dilution) for $1 \mathrm{~h}$. After extensive washing, the blots were detected with chemiluminescent HRP substrate for 1-5 min (Immobilon ${ }^{\mathrm{Tm}}$ Western, Millipore Corporation, Billerica, USA), and the images were captured with a chemiluminescence/fluorescence image analysis system (Tanon 5200, Shanghai, China).

For POD isozyme activity staining, the protein gels were stained with 3,3'-diaminobenzidine at room temperature for $10 \mathrm{~min}$ [56]. The stained gels were photographed, and the digital images were processed and analyzed using PDQuest8.0 software (Bio-Rad, USA).

\section{2-DE and mass spectrometry}

IEF was performed with a PROTEAN IEF CELL system (Bio-Rad, USA) using $11 \mathrm{~cm}$ linear $\mathrm{pH}$ 4-7 IPG strips (Bio-Rad, USA). The proteins $(600 \mu \mathrm{g}$ in $220 \mu \mathrm{l})$ were passively loaded onto the strips, and IEF and subsequent SDS-PAGE were performed as previously described [57]. After electrophoresis, the protein gels were stained using CBB R350 and photographed using a DSLR camera (Nikon D7000) in automatic mode.

The gel images were analyzed using PDQuest 8.0 software (Bio-Rad, USA) to compare statistically significant differences in protein accumulation in different samples. The spots were automatically detected and edited manually to improve accuracy. Matching was automatically obtained and manually checked. The relative volume parameter $(\% \mathrm{Vol})$ was used to evaluate protein level differences between gels. The \%Vol value of spots in fluoxetine-treated samples was normalized to the corresponding value in the control sample, and the obtained data were analyzed for significant differences using a one-way analysis of variance model based on three biological replications. Protein abundance was determined by taking the average normalized standardized spot peak area of all spots in 2-D gels. The spots with at least two-fold changes with statistically significant (t-test with $p<0.05$ ) and reproducible changes in 
abundance among the three growth periods of mesocotyls were selected for protein identification. A MALDI-TOF/ TOF mass spectrometer (ABI 5800, Applied Biosystems, CA, USA) was used in reflection mode to analyze the peptides from the tryptic digest as described previously [57]. The spectra were acquired in the positive ion mode and automatically submitted to Mascot 2.2 (http://www. matrixscience.com) for identification against the NCBInr database (February 17, 2017; species, Zea mays; 279,566 sequences). The search parameters were as follows: type of search: MALDI-TOF ion search; enzyme: trypsin; fixed modifications: carbamidomethyl $(\mathrm{C})$; variable modifications: acetyl (protein N-term), deamidated (NQ), dioxidation (W), oxidation (M); mass values: monoisotopic; protein mass: unrestricted; peptide mass tolerance: $\pm 100 \mathrm{ppm}$; fragment mass tolerance: $\pm 0.3 \mathrm{Da}$; max missed cleavages: 1 .

To avoid random matches, only ions with individual scores above the value indicated by MASCOT to identify or determine extensive homology $(\mathrm{p}<0.05)$ were considered for protein identification. Proteins with significant MASCOT scores $(>38)$ and at least three peptide sequences confirmed by MS/MS were considered positively identified $(\mathrm{p}<0.05)$. Unambiguous identification was judged by the number of MASCOT scores, matched peptide sequences, sequence coverage, MW and $p \mathrm{I}$. Moreover, a standard protein BLAST was run against the UniProtKB (http://www.UniProt.org/blast/) to search for homologous 'uncharacterized' or 'hypothetical' proteins.

\section{Bioinformatics analysis}

Database searches using individual tryptic fragments were performed using BLAST searches at NCBI (http:// www.ncbi.nlm.nih.gov/blast). The identified proteins were functionally classified according to the annotations in the UniProtKB database (https://www.UniProt.org/). Subcellular locations of the identified proteins were determined according to the annotation in UniProtKB or predicted at Plant-mPLoc server (http://www.csbio. sjtu.edu.cn/bioinf/plant-multi/). A Venn diagram was constructed using online server (http://bioinformatics. psb.ugent.be/webtools/Venn/). The heatmap was constructed using Microsoft Excel. The DAPs were annotated using Blast2GO software 5.0 (https://www.blast2 go.com/). Protein sequences were compared against the SwissProt database using a public NCBI Blast service (QBlast), and all programs were executed using default configurations. The meaningful matches from the Blast2GO analysis were annotated to GO categories (cellular component, molecular function, and biological process).

\section{RT-qPCR}

The total RNA of maize mesocotyls was extracted using RNA-Solv $v^{\circ}$ reagent (Omega Bio-Tek, USA) according to the manufacturer's instructions. The purity and concentration of total RNA were determined by a NanoDrop One spectrophotometer (Thermo Scientific, USA). Total RNA (10 $\mu \mathrm{g})$ was converted to cDNA using the FastKing RT Kit with gDNase (TIANGEN, China). The gene-specific primers (Additional file 3: Table S3) were designed using Primer Premier 5.0 and synthesized at the Biomed Cooperation (Beijing, China), with the ubiquitin gene as a loading control. RT-qPCR was performed using the StepOnePlus ${ }^{\text {тм }}$ RealTime PCR Instrument Thermal Cycling Block (Applied Biosystems). The PCR cycle was run as follows: $95^{\circ} \mathrm{C}$ for $3 \mathrm{~min}$, followed by 35 cycles at $95^{\circ} \mathrm{C}$ for $3 \mathrm{~s}$ and $58^{\circ} \mathrm{C}$ for $30 \mathrm{~s}$. The relative expression level of each gene was calculated from the cycle threshold $(\mathrm{Ct})$ value as $2^{-\Delta \mathrm{Ct}}(\Delta \mathrm{Ct}=$ each corresponding $\mathrm{Ct}$ value-the minimum $\mathrm{Ct}$ value), with the maximum expression level (set to 1.0) of each gene as a control.

\section{Supplementary information}

Supplementary information accompanies this paper at https://doi.org/10. 1186/s12864-019-6109-z

Additional file 1: Table S1. Consensus analysis and relative abundance changes in mesocotyl proteins resolved in 2-DE. The relative abundances (volumes) of the spots were determined using PDQuest8.0 software.

Additional file 2: Table S2. Summary of the DAPs identified in maize mesocotyl.

Additional file 3: Table S3. Primers used in RT-qPCR.

Additional file 4: Figure S1. The 2-DE profiles of maize mesocotyl at $48 \mathrm{~h}, 84 \mathrm{~h}$ and $132 \mathrm{~h}$. Maize mesocotyl proteins $(600 \mu \mathrm{g})$ were resolved by IEF using $11 \mathrm{~cm}$ pH 4-7 IPG dry strips. Secondary SDS-PAGE was carried out on a $12.5 \%$ resolving gel. The proteins were visualized using CBB R350 staining. Spots of relatively abundant proteins in the maize mesocotyl at $48 \mathrm{~h}, 84 \mathrm{~h}$ and $132 \mathrm{~h}$ with at least a two-fold change in abundance are indicated with a red line.

Additional file 5: Figure S2. Pie charts of the DAPs identified from the maize mesocotyl. A, Classification of the DAPs based on molecular function. B, Classification of the DAPs based on subcellular localization.

\section{Abbreviations}

2-DE: Two-dimensional electrophoresis; CBB: Coomassie brilliant blue; Ct: Cycle threshold; DAPS: Differential abundance proteins; ER: Endoplasmic reticulum; GO: Gene ontolgy; HSP: Heat shock protein; IAA: Indole-3-acetic acid; IEF: Isoelectric focusing; MALDI-TOF/TOF: Matrix-assisted laser desorption/ionization time-of flight/time-of-flight; MS: Mass spectrometry; POD: Peroxidase

\section{Acknowledgements}

We thank Misses Zengzi Qi and Mengjie Shi for assistence in cellulose content assay and RT-PCR. This study is dedicated to our hard effort and soft memory.

\section{Authors' contributions}

LJN and ZKW performed the experiments; LJN, ZKW, HL, XLW and WW analyzed the data and performed software application and data visualization; LJN and WW wrote the paper; WW conceived and designed the experiments. All authors read and approved the final manuscript.

\section{Funding}

This research was partly supported by National Natural Science Foundation of China (grant 31771700).

\section{Availability of data and materials}

All data have been presented in the main paper or additional supporting files. 


\section{Ethics approval and consent to participate}

Not applicable.

\section{Consent for publication}

Not applicable.

\section{Competing interests}

The authors declare that they have no competing interests.

Received: 11 June 2019 Accepted: 20 September 2019

Published online: 22 October 2019

\section{References}

1. Kutschera U, Wang ZY. Growth-limiting proteins in maize coleoptiles and the auxin-brassinosteroid hypothesis of mesocotyl elongation. Protoplasma. 2016;253:3-14

2. Bandurski RS, Schulze A, Dayanandan P, Kaufman PB. Response to gravity by Zea mays seedlings. I. Time course of the response. Plant Physiol. 1984;74:284-8.

3. Sagi G, Katz A, Guenoune-Gelbart D, Epel BL. Class 1 reversibly glycosylated polypeptides are plasmodesmal-associated proteins delivered to plasmodesmata via the Golgi apparatus. Plant Cell. 2005;17:1788-800.

4. Markelz NH, Costich DE, Brutnell TP. Photomorphogenic responses in maize seedling development. Plant Physiol. 2003;133:1578-91.

5. Maniou F, Chorianopoulou SN, Bouranis DL. New insights into trophic aerenchyma formation strategy in maize (Zea mays L.) organs during sulfate deprivation. Front Plant Sci. 2014:5:581.

6. Brovko FA, Vasil'eva VS, Lushnikova AL, Selivankina SY, Karavaiko NN, Boziev KM, Shepelyakovskaya AO, Moshkov DA, Pavlik LL, Kusnetsov W, et al. Cytokinin-binding protein $(70 \mathrm{kDa})$ from etioplasts and amyloplasts of etiolated maize seedlings and chloroplasts of green plants and its putative function. J Exp Bot. 2010;61:3461-74.

7. Sauter A, Hartung W. The contribution of internode and mesocotyl tissues to root-to-shoot signalling of abscisic acid. J Exp Bot. 2002;53:297-302.

8. Saab IN, Ho TH, Sharp RE. Translatable RNA populations associated with maintenance of primary root elongation and inhibition of mesocotyl elongation by abscisic acid in maize seedlings at low water potentials. Plant Physiol. 1995;109:593-601.

9. Walton JD, Ray PM. Evidence for receptor function of auxin binding sites in maize. Red light inhibition of mesocotyl elongation and auxin binding. Plant Physiol. 1981;68:1334-8.

10. Dubois PG, Olsefski GT, Flint-Garcia S, Setter TL, Hoekenga OA, Brutnell TP. Physiological and genetic characterization of end-of-day far-red light response in maize seedlings. Plant Physiol. 2010;154:173-86.

11. Viereck R, Kirsch M, Low R, Rausch T. Down-regulation of plant V-type $H^{+}$-ATPase genes after light-induced inhibition of growth. FEBS Lett. 1996;384:285-8.

12. Jones AM, Cochran DS, Lamerson PM, Evans ML, Cohen JD. Red lightregulated growth. I. Changes in the abundance of indoleacetic acid and a 22-kilodalton auxin-binding protein in the maize mesocotyl. Plant Physiol. 1991;97:352-8

13. Walton JD, Ray PM. Auxin controls Golgi-localized glucan synthetase activity in the maize mesocotyl. Planta. 1982;156:309-13.

14. Soga K, Harada K, Wakabayashi K, Hoson T, Kamisaka S. Increased molecular mass of hemicellulosic polysaccharides is involved in growth inhibition of maize coleoptiles and mesocotyls under hypergravity conditions. J Plant Res. 1999;1 12:273-8.

15. Momonoki YS. Asymmetric distribution of glucose and indole-3-acetyl-myoinositol in geostimulated Zea mays seedlings. Plant Physiol. 1988;87:751-6.

16. Momonoki YS. Asymmetric distribution of acetylcholinesterase in gravistimulated maize seedlings. Plant Physiol. 1997;114:47-53.

17. Kunzelmann P, Schäfer E. Phytochrome-mediated phototropism in maize mesocotyls. Relation between light and Pfr gradients, light growth response and phototropism. Planta. 1985;165:424-9.

18. lino M. Inhibitory action of red light on the growth of the maize mesocotyl: evaluation of the auxin hypothesis. Planta. 1982;156:388-95.

19. Vanderhoef LN, Briggs WR. Red light-inhibited mesocotyl elongation in maize seedlings: I. The auxin hypothesis. Plant Physiol. 1978;61:534-7.

20. Camp PJ, Wickliff JL. Light or ethylene treatments induce transverse cell enlargement in etiolated maize mesocotyls. Plant Physiol. 1981;67:125-8

21. Borucka J, Fellner M. Auxin binding proteins ABP1 and ABP4 are involved in the light-and auxin-induced down-regulation of phytochrome gene PHYB in maize mesocotyl. Plant Growth Regul. 2012;68:503-9.
22. Ljung K. Auxin metabolism and homeostasis during plant development. Development. 2013;140:943-50.

23. Cona A, Rea G, Botta M, Corelli F, Federico R, Angelini R. Flavin-containing polyamine oxidase is a hydrogen peroxide source in the oxidative response to the protein phosphatase inhibitor cantharidin in Zea mays L. J Exp Bot. 2006;57:2277-89.

24. Liu H, Zhang L, Wang J, Li C, Zeng X, Xie S, Zhang Y, Liu S, Hu S, Wang J, et al. Quantitative trait locus analysis for deep-sowing germination ability in the maize IBM syn10 dh population. Front Plant Sci. 2017;8:813.

25. Zhang H, Ma P, Zhao Z, Zhao G, Tian B, Wang J, Wang G. Mapping QTL controlling maize deep-seeding tolerance-related traits and confirmation of a major QTL for mesocotyl length. Theor Appl Genet. 2012;124:223-32.

26. Troyer AF. The location of genes governing long first internode of corn. Genetics. 1997;145:1149-54.

27. Zhao G, Wang J. Effect of gibberellin and uniconazole on mesocotyl elongation of dark-grown maize under different seeding depths. Plant Prod Sci. 2008;11:423-9.

28. Zhao G, Fu J, Wang G, Ma P, Wu L, Wang J. Gibberellin-induced mesocotyl elongation in deep-sowing tolerant maize inbred line 3681-4. Plant Breed. 2010;129:87-91.

29. Kutschera U, Deng Z, Oses-Prieto JA, Burlingame AL, Wang Z-Y. Cessation of coleoptile elongation and loss of auxin sensitivity in developing rye seedlings: a quantitative proteomic analysis. Plant Signal Behav. 2010;5:509-17.

30. Cleland RE. In: Davies PJ, editor. Auxin and Cell Elongation, Plant Hormones. Biosynthesis, Signal Transduction, Action. New York: Springer-Verlag; 2010. p. 204-20

31. Kutschera U, Schopfer P. Effect of auxin and abscisic acid on cell wall extensibility in maize coleoptiles. Planta. 1986;167:527-35.

32. Stevenson TT, Cleland RE. Osmoregulation in the Avena coleoptile in relation to auxin and growth. Plant Physiol. 1981;67:749-53.

33. Keegstra K. Plant cell walls. Plant Physiol. 2010;154:483-6.

34. Carpita NC, Kanabus J. Chemical structure of the cell walls of dwarf maize and changes mediated by gibberellin. Plant Physiol. 1988;88:671-8.

35. Shannon JC, Hanson JB, Wilson CM. Ribonuclease levels in the mesocotyl tissue of Zea mays as a function of 2,4-dichlorophenoxyacetic acid application. Plant Physiol. 1964;39:804-9.

36. Mayer U, Jürgens $\mathrm{G}$. Microtubule cytoskeleton: a track record. Curr Opin Plant Biol. 2002;5:494-501.

37. Sadiq I, Fanucchi F, Paparelli E, Alpi E, Bachi A, Alpi A, Perata P. Proteomic identification of differentially expressed proteins in the anoxic rice coleoptile. J Plant Physiol. 2011;168:2234-43.

38. Li J, Dickerson TJ, Hoffmann-Benning S. Contribution of proteomics in the identification of novel proteins associated with plant growth. J Proteome Res. 2013;12:4882-91.

39. Somerville C. Cellulose synthesis in higher plants. Annu Rev Cell Dev Biol. 2006;22:53-78.

40. Guerriero G, Fugelstad J, Bulone V. What do we really know about cellulose biosynthesis in higher plants? J Integr Plant Biol. 2010;52:161-75.

41. van Erp H, Walton JD. Regulation of the cellulose synthase-like gene family by light in the maize mesocotyl. Planta. 2009;229:885-97.

42. Taiz L. Plant cell expansion: regulation of cell wall mechanical properties. Annu Rev Plant Physiol. 1984;35:585-657.

43. Cleland RE, Rayl DL. Mechanisms of auxin-induced plant cell elongation. Plant Physiol. 1977:60:709-12.

44. Kim SH, Shinkle JR, Roux SJ. Phytochrome induces changes in the immunodetectable level of a wall peroxidase that precede growth changes in maize seedlings. Proc Natl Acad Sci U S A. 1989;86:9866-70.

45. Fry SC. Cross-linking of matrix polymers in the growing cell walls of angiosperms. Annu Rev Plant Physiol. 1986;37:165-86.

46. Goldberg R, Imberty A, Chu-Ba J. Development of isoperoxidases along the growth gradient in the mung bean hypocotyl. Phytochemistry. 1986;25:1271-4.

47. Ponnala L, Wang Y, Sun Q, Wijk KJ. Correlation of mRNA and protein abundance in the developing maize leaf. Plant J. 2014;78:424-40.

48. Deng Z, Xu S, Chalkley RJ, Oses-Prieto JA, Burlingame AL, Wang ZY, Kutschera $U$. Rapid auxin-mediated changes in the proteome of the epidermal cells in rye coleoptiles: implications for the initiation of growth. Plant Biol. 2012;14:420-7.

49. Smart RE, Bingham GE. Rapid estimates of relative water content. Plant Physiol. 1974;53:258-60.

50. Masuko T, Minami A, Iwasaki N, Majima T, Nishimura S, Lee YC. Carbohydrate analysis by a phenol-sulfuric acid method in microplate format. Anal Biochem. 2005;339:69-72. 
51. Pan Q, Han X, Bai Y, Yang J. Advances in physiology and ecology studies on stored non-structure carbohydrates in plants. Chin Bull Bot. 2002;19:30-8.

52. Kladnik A. Maize kernels - fixation in FAA, embedding, sectioning and feulgen staining. Bio-protocol. 2013;3:e15.

53. Niu L, Zhang H, Wu Z, Wang Y, Liu H, Wu X, Wang W. Modified TCA acetone precipitation of plant proteins for proteomic analysis. PLoS One. 2018;13:e0202238.

54. Laemmli UK. Cleavage of structural proteins during the assembly of the head of bacteriophage T4. Nature. 1970;227:680-5.

55. Bradford MM. A rapid and sensitive method for the quantitation of microgram quantities of protein utilizing the principle of protein-dye binding. Anal Biochem. 1976;7:248-54.

56. Daudi A, O'Brien JA. Detection of hydrogen peroxide by DAB staining in Arabidopsis leaves. Bio-protocol. 2012;2:e263.

57. Wu X, Gong F, Yang L, Hu X, Tai F, Wang W. Proteomic analysis reveals differential accumulation of small heat shock proteins and late embryogenesis abundant proteins between ABA-deficient mutant vp5 seeds and wild-type Vp5 seeds in maize. Front Plant Sci. 2015;5:801.

\section{Publisher's Note}

Springer Nature remains neutral with regard to jurisdictional claims in published maps and institutional affiliations.

Ready to submit your research? Choose BMC and benefit from:

- fast, convenient online submission

- thorough peer review by experienced researchers in your field

- rapid publication on acceptance

- support for research data, including large and complex data types

- gold Open Access which fosters wider collaboration and increased citations

- maximum visibility for your research: over $100 \mathrm{M}$ website views per year

At BMC, research is always in progress.

Learn more biomedcentral.com/submissions 